\title{
Legitimacy Controls of Commercial Advertisements: A Comparative Study
}

\author{
Dr.Nashat Mahmoud Jaradt \\ Applied Science University,3201 Al Eker ‘623, Bahrain
}

\begin{abstract}
Commercial advertising is one of the most important topics that people face in their daily life. This research determines the methods of commercial advertisement in Islamic Sharia Provisions and Commercial transaction Law that are used in Bahrain as well as its importance in being able to study importance of commercial advertisements in marketing products of all kinds, whether they are goods or services, which contributes to the stability, progress and success of economic life, and the successful advertising contributes significantly to reducing the cost of the product through the optimal promotion of it. With the growing importance of commercial advertisements, we cannot leave it alone, so the rules and regulations governing controlling the content of commercial advertisements of all kinds must be put in place, considering that they affect the doctrine or principles of general community morals, The Islamic economics considered as the mediating justice between the capitalist and socialist systems. In fact, those who follow the reality of commercial advertisements, which are broadcast by all advertising media general in Arab world and specially in Bahrain, find their severe lack of controls and considerate standards for the validity of advertising. The paper has placed a specific focus on the laws, regulations, and governmental bodies, Islamic Sharia law. This paper will not only rely on the Sharia Provisions but also text books, internet resources, regulations, statutory. The information was examined with the view to make recommendations for the best practice.
\end{abstract}

Keywords: China insurance industry, Foreign fund, Challenge

DOI: $10.7176 / \mathrm{IAGS} / 87-03$

Publication date:October $31^{\text {st }} 2020$

\section{Introduction}

The advertising is a means of transmitting ideas and information to people with the aim of changing or strengthening their opinions, as historical evidence indicates that the first convincing declaration appeared in the form of silver coins in the city of Cyrene in North Africa half a century before the birth of Christ. The Babylonians and Assyrians also resorted to the advertisement engraved and embossed on clay, and also to announce rewards for creators, knights, and others. In the early seventeenth century, there was a development in advertising as a result of the publication of the first English newspaper, The Weekly News in 1622. In 1710, the concept of competitive advertising emerged in comparison with pioneering advertising with the aim of identifying unknown goods and services in an attempt to persuade consumers to acquire them. As for competitive advertising, drug manufacturers are the first to use the process of advertising the drug in magazines and newspapers. After the Second World War, the advertising industry flourished remarkably in the promotion of goods and services, in which the economy recovered and productivity increased, which led to the intense competition, the expansion of markets, the high rates of mass entry, the rise in the level of luxury and other factors, which prompted advertisers to find the best way to know their products and services, It is the advertisement of these products and services in order to persuade and entice the masses to purchase. . Commercial advertising is considered at the present time one of the most prominent features of the era and necessity of modern life because it contains many benefits for the consumer and the producer and for the role it plays in the field of commercial competition, which left this development a great impact on legal and jurisprudential adjustments and the imposition of Sharia rulings on commercial advertising. These judgments have an impact on the economic movement in which the world has reached

Its climax in the ability to deliver what he wants within minutes through advanced communication devices represented by satellite, internet, and mobile channels ${ }^{1}$. This was marred by the commercial advertisement, legal violations, and Sharia violations, by the emergence of cases of fraud and forgery, the introduction of forbidden images and shameless recordings, and the advertisement of forbidden goods such as alcohol, parties, and forbidden entertainment.

Accordingly, commercial advertising plays a dangerous role in the commercial environment, which requires information related to and affecting the pattern of production and various services for presenting it to the consumer not to harm the consumer or the legal and legitimate systems ${ }^{2}$.

1 - Bashir Al-Allaq and A. Ali Rababaa, Promotion and Commercial Advertising, Al-Yazouri Scientific Publishing and Distribution House, 2002 AD. Pp. 129-131.

2 - Musab al-Samarrai, forbidden commercial advertisement and the consequent effect on completing the sale or terminating a jurisprudence study. A study presented to the University of Samarra. P. 2 
Commercial advertising, its characteristics and types.

Commercial advertising has its roots in the depths of transactional jurisprudence and is not something new, and the development that is taking place is an evolution in methods and means, and although some means are still continuing to this day, advertising in past centuries relied on presenting the surplus to others, than taking the image of calling for commodities and describing them under The consumer makes purchases, then relies on drawings and signals to identify the sellers and the goods.

The sharia jurists have explained its provisions, and the jurists have stipulated the goods are to sale or shown, called, or presented to buyers in a public auction, the jurists have stipulated the validity of the sale with knowledge of what is contracted upon. The Sales, which is one of the means of advertising, and it also includes news of the specifications of the contractee, and news is a means of advertising ${ }^{1}$.

Definition of Advertising

The meaning of advertisement is showing, publicity, and disclosure, and it is contrary to secret and concealment, and it is said: the matter is made public and announced, and publicly, appeared and spread a hidden disagreement, and publicly other than the secret, a man is said in public, that is, his order appears, and publicity, and boldness, in the sense of appearing and manifesting, flips out loudly by saying, and reading it if it appears and announced. The advertisement was also defined as: "The art of printed sales." It was defined as "a form of sales presentation and promotion of ideas, goods and services of an impersonal and paid nature, which is done by a specific sponsor."

The British Advertising Association (BAA) defined the advertisement as: "one of the means for the purpose of buying and selling goods and services." It also defined: "the impersonal means of presenting ideas, goods and services, promoting them, confirming their presence and praising them, by means of a known body for a paid fee."

Commercial advertising is also defined as an activity carried out by various media outlets and agencies in disseminating information and data on goods, services or ideas in various publishing media with the intention of selling them, or assisting in selling or accepting them in exchange for payment by a specific person.

The commercial advertisement is also defined as: "a medium of communication between the seller and the buyer." Also, it is: "an impersonal means of communication between the seller and the buyer2.

The first function of the advertisement is the cognitive function. The jurists have indicated that one of the conditions for the validity of the sale is that the contract is made known to the followers.

Furthermore, Science and knowledge achieve the meaning of satisfaction with the sale, and likewise the satisfaction with the sale is one of the conditions of validity of the sale, and knowing the characteristics of the commodity will obtain satisfaction with it, and the commodity is linked to it in the mind of the buyer, and thus the basis is knowledge, then satisfaction, and that buying results ${ }^{3}$.

There is no doubt that the advertisement is closely related to society, as it represents a relationship between individuals (advertisers) and other members of society who are consumers. The advertisement is affected by the surrounding community as well as it affects it, as it is in line with the conditions of people's lives, their values and customs ${ }^{4}$.

\subsection{Sections of Commercial Advertising}

1.1 Advertise by geographic region:

- National declaration: that any company that decides to sell a specific type of its products, it needs to stimulate the demand for that type ${ }^{5}$. The national declaration is one of the methods for achieving this goal ${ }^{6}$. This advertisement made by the company for the purpose of convincing consumers that obtaining the advertised item will save them many sums of money. The national declaration is made by the producer of the goods in contrast to the advertisement made by the retailer, the national advertisement covers the state and depends on its publishing media such as newspapers, radio and television.

- Regional advertising: It is an advertisement that covers one city, and depends on the local stations, posters, banners and local newspapers for that city.

- International Declaration: It is used in export, and is directed to consumers in different countries, and depends on means of publication in these countries ${ }^{7}$.

\footnotetext{
1 - Hisham Al-Jazaery, Civil Consumer Protection Against Deceptive Advertising, A working paper presented to Consumer Protection, University of Applied Sciences, 2012.

2- Bride Crown from Dictionary Jewels. Al-Zubaidi 9/280 Separation of Al-Ain from Bab Al-Noon, Dar Al-Fikr, Lisan Al-Arab.

${ }^{3}$-Ibn Hajar Al-Asqalani, Fath Al-Bari, ed. Dar Al-Hadith, Cairo, first edition, 1998 AD / 1419 AH, p. 587. pg 624 Academy of the Arabic Language

${ }^{4}$ - Al-Waseet Dictionary, p. 624 The Arabic Language Academy, fourth edition, 1426 AH / 2005 CE.

5 - Dr. Shaker Hamed Ali Hassan Jabal, Commercial Announcement, University Thought House, Alexandria, 2009 AD, p. 3.

${ }^{6}$-Dr. Naji Mualla, Scientific Fundamentals of Commercial Promotion and Advertising, The University of Jordan, Department of the National Library, Second Edition, 1996 AD, Jordan, p. 259.

7- Dr. Bashir Abbas Al-Alaq, Dr. Ali Muhammad Rababa, Promotion and Commercial Advertising, Al-Yazouri Scientific Publishing and Distribution House, 2007 AD, Amman-Jordan, p. 135.
} 
1.2 Advertising directed to the public:

This type of advertisement is directed to the consumer, and the industrial buyer, and is advertised in newspapers, in business newspapers and specialized publications, or in direct mail, including the advertisement of intermediaries, which is directed to distributors and agents.

\subsection{Sectoral Advertising (Retail):}

The place where the purchase is made is more important for the sector advertiser compared to the specific type of item being purchased, as retailers may advertise unrated goods and products, and this is common in SHOPPING GOODS, and some large retailers may promote the goods. Which they deal with in a manner similar to what a national advertiser does, that is, they use widespread advertising means to broadcast their advertising messages and publish their ads. In general, a sector advertiser operates in a much narrower geographical market than the available geographical market for a national advertiser ${ }^{1}$. It includes stimulating the impulse, and urging the consumer to buy the product regardless of the offered brands, and urges the consumer to buy the commodity with a specific brand and not others, and the impulse to buy by promotion, such as distributing coupons and free units ${ }^{2}$.

\subsection{Cooperative Advertising:}

This type of advertising involves all middlemen and producers sharing the costs of advertising campaigns. This arrangement helps middlemen to compete in local markets, so cooperative advertising is suitable for promoting private goods significantly. Cooperative advertising enables the producing company to obtain greater promotional efforts with the same advertising allocations, as the means of advertising often give the local advertiser (the mediator) reduced advertising prices compared to the prices they request from the producers ${ }^{3}$.

1.5 Advertise by goal:

The advertisement is divided according to the goal to educational, indicative, competitive, and reminder. Educational and it entails introducing the product, its characteristics, methods of use, its maintenance, and areas of use ${ }^{4}$

As for the indicative advertisement, it is intended to guide the consumer in the places of sale of goods, and their prices, but for competition, it is intended to highlight the characteristics of the commodity in relation to competing goods to urge the consumer to prefer buying from a specific product, and finally the reminder advertisement aims to remind the consumer and others about the commodity and its characteristics, advantages, places of sale and methods of use ${ }^{5}$.

1.6 Advertisement for business establishments:

Advertising is not limited to consumer goods and the relationship between distribution and advertising. However, there is another type of commodity, which is industrial or production commodities, which are commodities that are sold not for immediate consumption but for use in other industries, or specific productive uses ${ }^{6}$.

Industrial producers face similar problems to those of a national advertiser dealing with consumer goods. Advertising for industrial producers is an integral part of the marketing. Advertising designed to deliver a specific message to industrial buyers compared to ultimate consumers carries more than one name. Among the most prominent of these designations are commercial advertisements, industrial advertisements, professional advertisements, and advertisements for business establishments ${ }^{7}$. There are four subdivisions of the advertisement for business establishments, namely:

- Commercial advertising

- Industrial advertising

- Farm advertising

- professional advertising

\footnotetext{
1- Dr. Hassan Muhammad Khair al-Din, Public Relations, Principles and Application, Ain Shams Library, Wahdan House for Printing and Publishing 1976 AD, p. 29.

2 - Dr. Hana Abdel Halim, Al-Shaalan, The Arab Company for Publishing and Distribution, 1992 AD, p. 26.

3 - Dr. Ghazi Bin Zain Al-Din, The Arab Media Discourse, The Arab Company for Printing and Publishing, 1992 AD, p. 132.

${ }^{4}$ - Dr. Sami Abdul Aziz, d. Safwat Muhammad Al-Alam, Introduction to the Declaration, p. 29.

5 - we mean by the Sharia ruling here: Does the commercial advertisement take into account the five mandatory provisions and the concept of the Shari'a ruling: it is God's discourse related to the actions of those charged as a matter of necessity, choice or status, and the ruling is of two types: mandatory and positivist, al-Mustasfi in the fundamentals of al-Fiqh al-Ghazali / Commentary by Sheikh Ibrahim Muhammad Ramadan, Dar Al-Arqam Ibn Abi Al-Arqam, Beirut-Lebanon, 1414 AH / 1994 AD, Mukhtasar Ibn Al-Hajeb 220/1, Dar Al-Kutub, and a memorandum on Usul Al-Fiqh, Al-Shanqeeti, Dar Al-Busirah for Printing and Publishing, p. 11.

6- Badaa'a Al Sanai'a. Lakasani 9/81, Sheikh Ali Muhammad Al-Awad, and Sheikh Adel Ahmad Abdul-Muawjid, Dar Al-Kutub Al-Ilmiyyah, Labrut, first edition, $1418 \mathrm{AH} / 1997 \mathrm{AD}$.

7- Encyclopedia of Islamic Jurisprudence, 262/15 known as "Gamal Abdel Nasser" encyclopedia, Supreme Council for Islamic Affairs, Ministry of Endowments in Egypt 1418 AH / 1997AD, advertisement article.
} 
2. Commercial advertising in the Islamic system:

The commercial advertisement contain the five mandatory provisions, Recommended, Neutral, Reprehensible and Forbidden, The basic principle in the word commissioning is that it is derived from the assignment, and the principle is that it does not refer except to the prohibition, and the obligation where there is no assignment except in them, for the sake of carrying on the act or abandoning the fear of punishment, and the obligated in relation to what else is in the capacity not to be blamed, so there is no assignment except that they expanded in the release Exposing to everyone in a conquest, or cause it is only related to the action of the taxpayer, and the sale and purchase is entered under the letter of assignment because it is ordered or forbidden, or authorized, for requiring interests or evils to bring or push. The commercial advertisement is divided into duty, prohibited, disliked, and desirable. Or delegate, permissible ${ }^{1}$.

First: The duty declaration and The declaration is contain two-parts:

1 - It is every new matter that Muslims can harm to ignorance of it - this warning declaration is obligatory, such as: declare a false witness to warn people against him and saying: "This is a false witness, beware of it." And declaring the stone to the bankrupt debtor, and the stone on the ship, to warn Muslims From dealing with them, and now the bankrupt is announced in the official newspapers under the chapter on bankruptcy and it came in the blog: Shafi' said: "Whoever wants to congeal his son, let him bring him to the Sultan so that the Sultan will stop him, and circulate him in the markets and places, and the mosques, so that the Sultan is the one who stops him for people. , Or he seeks it in his assembly, and he attests to that, so whoever pledges allegiance to it, or purchases from it after that, it is rejected, From this text, it becomes clear that the matter of the bankrupt is announced, circumambulating him in places where people gather, and witnessing it so that people warn against dealing with him, and this publicity and announcement was the one available in the past.

2- It is every work that Muslims can obtain from good and compete in his request, so the guardian must announce this matter, so that everyone has an equal opportunity, such as announcing jobs, and the actions for which the guardian imposes rewards for those who perform them.

Second Forbidden advertising:

This includes something forbidden, such as advertising alcohol, intoxicants, drugs, pork, interestbased banking, and announcing night parties that include forbidden singing and forbidden dance performances, and every advertisement includes fraud, lying, deception, or illegal promotion for goods or services, as well as advertising a loan with interest ${ }^{2}$.

Third The hate advertisement

It is the one that depends on stimulating motives and developing excessive consumption, and it may reach the point of sanctity. For example: praising commodities and exaggerating praise for them, if it reaches the point of lying, deceit or fraud, or developing excessive consumption (extravagance) is prohibited ${ }^{3}$.

Fourth Advertising scars or desirable

It is represented in announcing the discounts on the condition that they are true, and such as announcing the sale at the factory price or the assignment, the "Assumption sale" and it was mentioned in the Shafi'i jurisprudence. Expense, because the method of scarring is delegated and the method of duty is obligatory, so the announcement of discounts is delegated ${ }^{4}$.

Fifth: A permissible or permissible declaration

The principle in things is permissible 5 .

3. Sharia controls for commercial advertising

There is a set of Sharia controls that are required to be present in the commercial advertisements so that these advertisements are permissible from the Sharia point of view, and these controls are drawn from the Holy Quran and the purified Sunnah, and other sources of Islamic legislation ${ }^{6}$.

- $\quad$ Avoid fraud and deception

The commercial declaration, which contains fraud, deception and fraud of the acts forbidden in Islam $^{7}$ and can be inferred from The Holy Quran: (Verily, those who purchase a small gain at the

\footnotetext{
1 - The Great Blog, by Imam Malik bin Anas Al-Asbahi, Novel Sahnoun 1995/6, authored by Hamdi Al-Demerdash, The Modern Library, Saida-Beirut, 1419 AH / 1999AD.

2 - The end of the needy, Ramli 315/4

3 - Al-Mughni by Ibn Qudama 6/1972, with the great explanation T / Dr. Muhammad Sharaf al-Din Khattab, d. Mr. Muhammad, Dar Al Hadith in Cairo, First Edition, 1996 AD.

4 - Saheeh Muslim, explained by Al-Nawawi 285/12, p. 286

5 - Dr. Shaker Jamed Ali Hassan Gabal, Commercial Advertising, University Thought House, Alexandria, 2009 AD, 18

6 - The end of al-Muhtaj al-Ramli 177/3

7 - Dr. Shaker Jamed Ali Hassan Gabal, Commercial Advertising, University Thought House, Alexandria, 2009 AD, 19.
} 
cost of Allah's Covenant and their oaths, they shall have no portion in the Hereafter ( Paradise). Neither will Allah speak to them, nor look at them on the Day of Resurrection, nor will He purify them, and they shall have a painful torment. ${ }^{1}$ ) The basic condition for trade was that it was about mutual consent between people, and there is no doubt that whoever bought something fraudulent or fraudulent, and he did not know about it, is not satisfied with it in reality, so the sale that included fraud, lying, deceit and fraud is a matter of consuming money unlawfully, so it is not permissible ${ }^{2}$. Commercial transactions in Islam are based on clarity and advice among people because the Messenger, peace be upon him, said: "Religion is advice. Religion is advice ${ }^{3}$. Religion is advice." For this, the advertiser must avoid fraud and deception in his commercial ads ${ }^{4}$.

- Avoid triggering instincts and desires

Among the virtues and good morals that Islam called for is not being alone and mixing between the sexes, or doing something that would provoke instincts and desires because of the destruction of societies and spreading outrageous desires in these matters ${ }^{5}$.

- $\quad$ Not to extravagance and waste

- Moderation in everything is required, and a virtue desirable for the Muslim to be adorned with, because God Almighty said: (And let not your hand be tied ( like a miser) to your neck, nor stretch it forth to its utmost reach(like a spendthrift), so that you become blameworth and in severe poverty ${ }^{6}$.

- Not to announce taboos.

Discouraged Islamic law on the announcement of the taboo, The God Almighty said: (Those who follow the Messenger, the Prophet who can either read nor write whom they find written with them in the Taurat and the Injeel he commands them for Al-Maruf and forbids them from Al-Munkar (i.e disbelief, polytheism of all kinds, and all that Islam has forbidden) he allows them as lawful At-Tayyibat (i.e. all good and lawful as regards things, deeds, beliefs, persons, foods) and prohibits them as unlawful Al-khabaith (i.e. all evil and unlawful as regards things, deeds, beliefs, persons, and foods) he releases them from their heavy burdens ( of Allah's Covenant with the children od Israel) and from the fetters (bindings) that were upon them. ${ }^{7}$ ).

Advertising is a means of promoting goods and products; If these ads include declaring forbidden things, then these ads are considered forbidden, and therefore forbidden ${ }^{8}$. The God Almighty said: (O ye who believe! Violate not the sanctity of the symbols of Allah, nor of the sacred month, nor of the animals brought for sacrifice, nor the garlands people or animal, and others nor the people coming to the Sacred House ( Makkah) seeking the bounty and good pleasure of their Lord. But when you finish the Ihram ( of Hajj or Umrah), you may hunt, and let not the hatred of some people in once stopping you from Al-Masjid-AlHaram (at Makkah) lead you to transgression (and hostility on your part). Help you one another in Al-Birr and At-Taqwa (virtue, righteousness and piety), but help one another in sin and transgression. And fear Allah. Verily, Allah is Severe in Punishment. ${ }^{9}$ ) The basic principle here is cooperation in righteousness and piety, and avoiding disobedience and prohibitions ${ }^{10}$.

3.1 The advertisement should not denounce and challenge the goods and products of others

Islam is a religion of interdependence and solidarity, the religion is believed in good for all. On the authority of Anas bin Malik, on the authority of the Prophet, may God's prayers and peace be upon him, states, "None of you believes until he loves for his brother what he loves for himself."

The Prophet, may God's prayers and peace be upon him, states in this hadith that the complete faith of a Muslim cannot be fulfilled until he loves for his brother what he loves for himself in terms of religion and the world, and hates for him what he hates for himself in his own brother.

A believer is not a true believer until he is satisfied with the people what he pleases for himself, and this comes from the perfection of the integrity of the heart, from cheating, deceit and envy. For the envy requires that the envious person hate that someone outweighs him in good, or equates him with it. Because he loves to be

\footnotetext{
1 - AL Quran Alkarim translated. Al-Imran: 77.

2 - Muhammad Ibn Abi Bakr Ibn Abd al-Qadir al-Razi - Mukhtar al-Sahah - Dar al-Hadith - Cairo - 1st floor - 1421 AH / 2000 AD - p. 211 , Ahmed bin Muhammad bin Ali al-Fayoumi al-Maqri - al-Misbah al-Munir - Dar al-Hadith - Cairo - 1st Edition - 1421 AH / 2000 AD - P. 213.

3. Jarallah Abu Al-Qasim Mahmoud bin Omar Al-Zamakhshari (d.538 AH) - The Basis of Rhetoric - House of Revival of Arab Heritage Beirut - Lebanon - 1st Edition - 1422 AH / 2001AD - pg 440.

4 - Muhammad bin Abi Bakr bin Abdul Qadir al-Razi - Mukhtar As-Sahha - previous reference - pg. 211.

5 -Dr. Abdul Aziz Muhammad Azzam - Jurisprudence Rules - Dar al-Hadith - Cairo - 1426 AH - 2005 AD - pg. 58.

6-AL Quran Alkarim translated. Israa: 29.

7 - AL Quran Alkarim translated . al'aeraf : 157

${ }^{8}$ Narrator: Tamim Al-Dari | Updated: Ibn Abd al-Barr | Source: Preface page or number: 21/284 | Summary of the updated ruling: It is correct

9. - AL Quran Alkarim translated. almayidat : 2

${ }^{10}$ - Pen: 4.
} 
distinguished by his virtues over people, and to be alone with them from them, and faith implies otherwise, which is for all believers to share with him in what God has given him of goodness.

From the previous it is clear that the Sharia came with love and altruism. Because of the interconnectedness and cohesion between the members of the same society, and that competition in Islamic law is something praiseworthy and not blameworthy, but this competition must be in accordance with a correct system derived from Islamic law ${ }^{1}$.

Also, the prohibition of contesting goods, services and competitive establishments in a commercial advertisement can be inferred as follows:

Do not be envious, do not argue, do not hate, do not deliberate, and do not sell some of you in order to sell one another, and be the servants of God the Muslim brothers, the brother of the Muslim. Every Muslim is forbidden to a Muslim,

his blood, money, honor and honor, and in a narration: The Messenger of God, may God's prayers and peace be upon him, said: He mentioned about you in the hadith of David, and he added to you, and what is lacking in it, and God does not look at you. With his fingers to his chest.

\section{Conclusion:}

we can not deny the great importance of commercial advertisements in marketing products of all kinds, whether they are goods or services, which contributes to the stability, progress and success of economic life, and the successful advertising contributes significantly to reducing the cost of the product through the optimal promotion of it. That leads to cumulative increases through marketing efforts - of which advertising is one of the components.

With the growing importance of commercial advertisements, we cannot leave it alone, so the rules and regulations governing controlling the content of commercial advertisements of all kinds must be put in place, taking into account that they affect the doctrine or principles of general community morals. - Islamic economics is the mediating justice between the capitalist and socialist systems, and it is self-standing and has its own ideology, as it recognizes the value of the individual and his rights, and the rights of society and balances between them. Rather, he made the individual for the group and the group for the individual through general solidarity between individuals. Discouraged Islamic law for the announcement of the taboo.

\section{Recommendations:}

In fact, those who follow the reality of commercial advertisements, which are broadcast by all advertising media day and night in our Arab world, find their severe lack of controls and considerate standards for the validity of advertising, so the researcher recommends the following:

- Calling for the establishment of specialized Sharia supervisory bodies, which includes all legal disciplines, media and marketing. Among its tasks will be controlling commercial advertisements and correcting errors in them.

Calling advertisers and advertising companies to take into account Sharia and legal controls before broadcasting them to the public.

- Putting in place legislation that requires advertising companies and advertisers to control the rules, with stiffening penalties, so that advertisers and advertising companies are obligated to abide by the controls set.

- The need to pay attention to contemporary issues, address them jurisprudently, and derive judgments related to them.

- The need to create legislations derived from Islamic law to regulate commercial advertising

The Islamic Sharia was characterized by a balance between conflicting interests and preferring the most beneficial to the positive legislation that is characterized by extremism towards the right or the left.

\section{References}

Bashir Al-Allaq and A. Ali Rababaa, Promotion and Commercial Advertising, Al-Yazouri Scientific Publishing and Distribution House, 2002 AD. Pp. 129-131.

Musab al-Samarrai, forbidden commercial advertisement and the consequent effect on completing the sale or terminating a jurisprudence study. A study presented to the University of Samarra. P. 2

Hisham Al-Jazaery, Civil Consumer Protection Against Deceptive Advertising, A working paper presented to Consumer Protection, University of Applied Sciences, 2012.

Bride Crown from Dictionary Jewels. Al-Zubaidi 9/280 Separation of Al-Ain from Bab Al-Noon, Dar Al-Fikr, Lisan Al-Arab.

Ibn Hajar Al-Asqalani, Fath Al-Bari, ed. Dar Al-Hadith, Cairo, first edition, 1998 AD / 1419 AH, p. 587. pg 624 Academy of the Arabic Language.

\footnotetext{
1- alrawi : 'anas bin malik | almahdath : albikhariu | almasdar : sahih albikharii alsafhat 'aw alraqm: 13 | khulasat hakam almahdath : sahihun.
} 
Al-Waseet Dictionary, p. 624 The Arabic Language Academy, fourth edition, 1426 AH / 2005 CE.

Dr. Shaker Hamed Ali Hassan Jabal, Commercial Announcement, University Thought House, Alexandria, 2009 AD, p. 3

Dr. Naji Mualla, Scientific Fundamentals of Commercial Promotion and Advertising, The University of Jordan, Department of the National Library, Second Edition, 1996 AD, Jordan, p. 259.

Dr. Bashir Abbas Al-Alaq, Dr. Ali Muhammad Rababa, Promotion and Commercial Advertising, Al-Yazouri Scientific Publishing and Distribution House, 2007 AD, Amman-Jordan, p. 135.

Dr. Hassan Muhammad Khair al-Din, Public Relations, Principles and Application, Ain Shams Library, Wahdan House for Printing and Publishing 1976 AD, p. 29.

Dr. Hana Abdel Halim, Al-Shaalan, The Arab Company for Publishing and Distribution, 1992 AD, p. 26.

Dr. Ghazi Bin Zain Al-Din, The Arab Media Discourse, The Arab Company for Printing and Publishing, 1992 AD, p. 132.

Dr. Sami Abdul Aziz, d. Safwat Muhammad Al-Alam, Introduction to the Declaration, p. 29.

Al-Arqam, Beirut-Lebanon, 1414 AH / 1994 AD, Mukhtasar Ibn Al-Hajeb 220/1, Dar Al-Kutub, and a memorandum on Usul Al-Fiqh, Al-Shanqeeti, Dar Al-Busirah for Printing and Publishing, p. 11.

Badaa'a Al Sanai'a. Lakasani 9/81, Sheikh Ali Muhammad Al-Awad, and Sheikh Adel Ahmad Abdul-Muawjid, Dar Al-Kutub Al-Ilmiyyah, Labrut, first edition, 1418 AH / 1997AD.

Encyclopedia of Islamic Jurisprudence, 262/15 known as "Gamal Abdel Nasser" encyclopedia, Supreme Council for Islamic Affairs, Ministry of Endowments in Egypt 1418 AH / 1997AD, advertisement article.

The Great Blog, by Imam Malik bin Anas Al-Asbahi, Novel Sahnoun 1995/6, authored by Hamdi Al-Demerdash, The Modern Library, Saida-Beirut, 1419 AH / 1999AD.

The end of the needy, Ramli 315/4.

Al-Mughni by Ibn Qudama 6/1972, with the great explanation T / Dr. Muhammad Sharaf al-Din Khattab, d. Mr. Muhammad, Dar Al Hadith in Cairo, First Edition, 1996 AD.

Saheeh Muslim, explained by Al-Nawawi 285/12, p. 286.

Dr. Shaker Jamed Ali Hassan Gabal, Commercial Advertising, University Thought House, Alexandria, 2009 AD, 18.

The end of al-Muhtaj al-Ramli 177/3

Dr. Shaker Jamed Ali Hassan Gabal, Commercial Advertising, University Thought House, Alexandria, 2009 AD, 19.

AL Quran Alkarim translated. Al-Imran: 77.

Muhammad Ibn Abi Bakr Ibn Abd al-Qadir al-Razi - Mukhtar al-Sahah - Dar al-Hadith - Cairo - 1st floor - 1421 AH / 2000 AD - p. 211, Ahmed bin Muhammad bin Ali al-Fayoumi al-Maqri - al-Misbah al-Munir - Dar alHadith - Cairo - 1st Edition - 1421 AH / 2000 AD - P. 213.

Jarallah Abu Al-Qasim Mahmoud bin Omar Al-Zamakhshari (d.538 AH) - The Basis of Rhetoric - House of Revival of Arab Heritage - Beirut - Lebanon - 1st Edition - 1422 AH / 2001AD - pg 440.

Muhammad bin Abi Bakr bin Abdul Qadir al-Razi - Mukhtar As-Sahha - previous reference - pg. 211.

Dr. Abdul Aziz Muhammad Azzam - Jurisprudence Rules - Dar al-Hadith - Cairo - 1426 AH - 2005 AD - pg. 58.

AL Quran Alkarim translated. Israa: 29.

AL Quran Alkarim translated . al'aeraf : 157.

Narrator: Tamim Al-Dari | Updated: Ibn Abd al-Barr | Source: Preface page or number: 21/284 | Summary of the updated ruling: It is correct .

AL Quran Alkarim translated. almayidat : 2

Pen: 4.

alrawi : 'anas bin malik | almahdath : albikhariu | almasdar : sahih albikharii alsafhat 'aw alraqm: 13 | khulasat hakam almahdath : sahihun. 